\title{
Involvement of the orphan nuclear estrogen receptor-related receptor $\alpha$ in osteoclast adhesion and transmigration
}

\author{
Edith Bonnelye ${ }^{1,2}$, Frédéric Saltel ${ }^{1 \star \dagger}$, Anne Chabadel ${ }^{1 \star}$, Ralph A Zirngibl ${ }^{3}$, \\ Jane E Aubin ${ }^{3}$ and Pierre Jurdic ${ }^{1}$ \\ ${ }^{1}$ Institut de Génomique Fonctionnelle de Lyon, Université de Lyon, Université Lyon 1, CNRS, INRA, Ecole Normale Supérieure de Lyon, 69007 Lyon, France \\ ${ }^{2}$ INSERM U664, Faculté de Médecine RTH Laennec, Rue Guillaume Paradin, 69372 Lyon Cedex 08, France \\ ${ }^{3}$ Department of Molecular Genetics, Medical Sciences Building, 1 King's College Circle, Toronto, Ontario, Canada M5S 1A8 \\ (Correspondence should be addressed to E Bonnelye at INSERM U664, Faculté de Médecine RTH Laennec; Email: edith.bonnelye@inserm.fr) \\ *(F Saltel and A Chabadel contributed equally to this work) \\ ${ }^{\dagger}$ (F Saltel is now at European Institute of Chemistry and Biology, Unité INSERM 889, Université Victor Segalen Bordeaux 2, IFR66, 2, rue Robert Escarpit, \\ 33600 Pessac, France)
}

\begin{abstract}
The orphan nuclear receptor, estrogen receptor-related receptor $\alpha(E R R \alpha)$ is expressed in osteoblasts and osteoclasts (OCs) and has been proposed to be a modulator of estrogen signaling. To determine the role of ERR $\alpha$ in OC biology, we knocked down ERR $\alpha$ activity by transient transfection of an siRNA directed against ERR $\alpha$ in the RAW264.7 monocytemacrophage cell line that differentiates into OCs in the presence of receptor activator of nuclear factor $\kappa B$-ligands and macrophage colony-stimulating factor. In parallel, stable RAW cell lines expressing a dominant-negative form of ERR $\alpha$ and green fluorescent protein (RAW-GFP-ERR $\alpha \Delta \mathrm{AF} 2$ ) were used. Expression of OC markers was assessed by real-time $\mathrm{PCR}$, and adhesion and transmigration tests were performed. Actin cytoskeletal organization was visualized using confocal microscopy. We found that RAW264.7 cells expressing siRNA directed against ERR $\alpha$ and RAW-GFP$\mathrm{ERR} \alpha \Delta \mathrm{AF2}$ OCs displayed abnormal spreading, and decreased osteopontin and $\beta 3$ integrin subunit expression compared with the corresponding control cells. Decreased adhesion and the absence of podosome belts concomitant with abnormal localization of c-src were also observed in RAW-GFP-ERR $\alpha \Delta$ AF2-derived OCs. In addition, RAW-GFP$\mathrm{ERR} \alpha \Delta \mathrm{AF} 2$-derived OCs failed to transmigrate through osteoblast cell layers. Our data show that the impairment of $\mathrm{ERR} \alpha$ function does not alter OC precursor proliferation and differentiation but does alter the adhesion/spreading and migration capacities of mature OCs.
\end{abstract}

Journal of Molecular Endocrinology (2010) 45, 365-377

\section{Introduction}

Osteoclasts (OCs) are large multinucleated cells of hematopoietic origin formed by the differentiation and fusion of mononuclear monocyte-macrophage lineage precursors after stimulation by receptor activator of nuclear factor $\kappa \mathrm{B}$-ligands (RANKL) and macrophage colony-stimulating factors (M-CSF; Boyle et al. 2003). OC formation is associated with the expression of markers such as tartrate-resistant acid phosphatase (TRAP) and calcitonin receptor (CTR). Moreover, OCs are highly polarized cells, and several studies have identified a series of factors involved in OC spreading, polarity, adhesion, and migration, such as osteopontin (OPN), integrin subunits $\alpha \mathrm{v}, \beta 1, \beta 3, \beta 5$, cluster of differentiation 44 (CD44), c-src, and tumor necrosis factor receptor-associated factor 6 (Traf6; Denhardt \& Noda 1998, Chellaiah \& Hruska 2003, Chabadel $e t$ al. 2007, Teitelbaum 2007). OCs are highly migratory on bone surfaces or through collagen
(Domon et al. 2002, Delaisse et al. 2003, Saltel et al. 2004). Recently, we have found that OCs are also able to transmigrate through cell layers, a process that involves c-src and metalloproteinases (MMPs; Saltel et al. 2006). Moreover, OCs exhibit several features, such as podosomes, that are associated with cell adhesion, migration, and invasion. In fact, we have previously shown that mature OCs, when spread on glass or plastic, form highly dynamic podosome belts (Destaing et al. 2003, Jurdic et al. 2006) at their periphery; whereas, when cultured on apatite mineral (corresponding to the mineral phase of bone), they exhibit another actin-rich structure, the sealing zone, which seals off the resorption area (Vaananen et al. 2000, Saltel et al. 2004, 2008).

Nuclear steroid receptors are transcription factors involved in various physiological regulatory processes, including multiple processes in bone (Gennari et al. 2007). The superfamily to which nuclear receptors belong comprises both ligand-dependent molecules such as ERs and a large number of so-called orphan 
receptors, for which no ligands have yet been determined (Benoit et al. 2006). Three orphan receptors, ER-related receptor $\alpha(\mathrm{ERR} \alpha), \mathrm{ERR} \beta$, and ERR $\gamma$ (NR3B1, NR3B2, and NR3B3 respectively, according to the Nuclear Receptors Nomenclature Committee 1999), share similarities with $\mathrm{ER} \alpha$ and ER $\beta$ (NR3A1 and NR3A2 respectively; Green et al. 1986, Kuiper et al. 1996), but they do not bind estrogen (Greschik et al. 2002, Kallen et al. 2004). Sequence alignment of $\mathrm{ERR} \alpha$ and the ERs reveals a high similarity $(68 \%)$ in the 66 amino acids (aa) of the DNA-binding domain, but only a moderate similarity $(36 \%)$ in the ligand-binding domain, which may explain the fact that ERR $\alpha$ recognizes the same DNA-binding elements as ERs but does not bind estrogen (Giguere et al. 1988). Several studies have shown that ERR $\alpha$ may activate gene transcription constitutively essentially through its coactivator-binding domain AF-2 (Vanacker et al. 1999, Kallen et al. 2004). ERR $\alpha$ regulates fatty acid oxidation and the adaptative bioenergetic response (Luo et al. 2003, Huss et al. 2007). ERR $\alpha$ is highly expressed in skeletal (bone and cartilage) tissues (Bonnelye et al. $2001,2007)$ and has been reported to regulate osteoblast development and bone formation in vitro (Bonnelye et al. 2001, 2007) and in vivo (Delhon et al. 2009, Teyssier et al. 2009). One study out of two has also described an ESRRA gene regulatory variant that is associated with bone mineral density and index in premenopausal women (Laflamme et al. 2005, Giroux et al. 2008).

In addition to its expression in osteoblasts, we have previously described ERR $\alpha$ expression in multinucleated TRAP-positive OCs in rat femurs after ovariectomy (Bonnelye et al. 2002). We therefore decided to address the possible function of ERR $\alpha$ in osteoclastogenesis, including OC differentiation and adhesion-transmigration activities, using RAW264.7 cells transfected with an siRNA directed against ERR $\alpha$ or with a wild-type (WT) or a dominant-negative form of $E R R \alpha$.

\section{Materials and methods}

\section{Reagents}

A pEGFP vector (Clontech) was used to obtain the stable RAW-GFP $(\mathrm{Ct})$ and RAW-GFP-ERR $\alpha \Delta$ AF2 (clones 1, 2, and 3) cell lines. Mouse ERR $\alpha$ cDNA (WT and $\triangle \mathrm{AF} 2$ ) was obtained from mRNA extracted from primary OCs derived from spleen cells on day 6 , using reverse transcription (RT)-PCR with specific primers ((NM_007953.1): ERR $\alpha$ upstream (177 bp): TCC AGC ACC ATG TCC AGC; ERR $\alpha$ downstream (WT) (1-1436 bp): CCA CCC CTT GCC TCA GTC CAT; ERR $\alpha$ downstream ( $\triangle$ AF2): TCA TGC TGT CTG GCG GA (1-1341 bp); helix 11-12 deletion (42 aa);
Bonnelye et al. 2007). Amplicons were sequenced for verification. Anti-phospho-src (pTyr418) was from Abcam (ab4816); anti-integrin $\beta 3$ chain was from BD (San Jose, CA, USA); anti-GFP was from Roche (monoclonal antibody mixture, clones 7.1 and 13.1). CY5-conjugated secondary antibodies (anti-rabbit, -mouse, -goat, and -hamster; 1/3000 final dilution) were from Jackson ImmunoResearch Laboratories (West Grove, PA, USA). The F-actin distribution was revealed with Alexa Fluor-546-Phalloidin from Molecular Probes (Eugene, OR, USA).

\section{Cell culture}

MC3T3-E1 cells were cultured in $\alpha$-MEM containing $10 \%$ fetal bovine serum (FBS; Zirngibl et al. 2008). On the day of transfection, cells were transfected using Lipofectamine 2000 (Invitrogen). Spleen cells from 6-week-old OF1 male mice, none modified RAW264.7 and RAW264.7 (GFP(Ct) and GFP- $\Delta$ AF2) cells were cultured for 8 and 6 days respectively in differentiation medium: $\alpha$-MEM containing 10\% FCS (BioWest, Nuaille, France), $20 \mathrm{ng} / \mathrm{ml} \mathrm{M-CSF}$ and $20 \mathrm{ng} / \mathrm{ml}$ soluble recombinant RANKL (Destaing et al. 2003).

\section{RNA interference (siRNA)}

The ERR $\alpha$ siRNA sequence was GCU AGU GCU CAG CUC UCU ACC CAA (403-426 bp) (Invitrogen). This sequence was rigorously analyzed by BLAST search, and no homologies were found; this included no homology with any of the $\operatorname{ER} \alpha, \operatorname{ER} \beta, \operatorname{ERR} \beta$, or $\operatorname{ERR} \gamma$, or with any other currently known nuclear receptors. The recommended negative control (Sc) by the manufacturer was used (Medium GC stealth RNA interference negative control duplexes; Invitrogen). ERR $\alpha$ siRNA and Sc were transfected twice into RAW cells following the manufacturer's protocol on days 3 and 4 after the addition of RANKL. mRNA was extracted on day 5.

\section{Transactivation assay}

HeLa cells were plated at 40000 cells/well on a 24-well plate in DMEM (Sigma D5796) plus 10\% FBS the day before transfection and incubated in a humidified incubator at $37^{\circ} \mathrm{C}$ in a $95 \%$ air- $5 \% \mathrm{CO}_{2}$ atmosphere. Media were changed just prior to transfection and again $24 \mathrm{~h}$ after transfection. Cells were transfected with Lipofectamine 2000 (Invitrogen) following the manufacturer's protocol using $100 \mathrm{ng}$ expression vector, $200 \mathrm{ng}$ luciferase reporter vector, and $10 \mathrm{ng}$ pRL tk luc (Promega) for normalization. The pGL3 BSP reporter contains the rat bone sialoprotein promoter from -448 to -1 relative to the transcription start site cloned into pGL3B (Promega). Luciferase activities 
were measured $48 \mathrm{~h}$ later on an EG\&G Berthold Microplate Luminometer LB96V (EG\&G Berthold GmbH \& Co., Oak Ridge, TN, USA) using the DualLuciferase reporter assay system (Promega). Transfections were repeated at least three times, and a representative experiment is shown.

\section{Osteoclast differentiation and spreading test}

After 6 days, GFP(Ct) and GFP- $\triangle \mathrm{AF} 2(1,2$, and 3) cells were fixed with paraformaldehyde (PFA; Merck), then stained for TRAP using a histochemical kit (no. 387; Sigma-Aldrich), following the manufacturer's instructions. Multinucleated TRAP-positive cells containing three or more nuclei were counted as OCs. To quantify OCs spreading, OCs derived from GFP(Ct) and GFP$\triangle \mathrm{AF} 2(1,2$, and 3) cells were fixed and labeled with Alexa Fluor-546-Phalloidin to visualize, by fluorescence, specific F-actin structure-containing podosome belts that characterize spread OCs. Spread OCs were quantified by counting the podosome belts versus the total number of OCs, under a X40 (NA 1.0) Zeiss PlanAchromat objective and expressed as percentage. Results were plotted as the mean percentage of podosome belt number \pm s.D. of triplicate wells for GFP(Ct)- and GFP- $\triangle$ AF2 (1, 2, and 3)-derived OCs and for siRNA-transfected cells and are representative of two independent experiments each.

\section{Adhesion test}

OCs were detached and re-seeded on plastic in 12-well plates. The OCs were incubated at $37^{\circ} \mathrm{C}$ in PBS containing $0.25 \mathrm{mM}$ EDTA (PBS-EDTA) $4 \mathrm{~h}$ later. The incubation was stopped either immediately $(T=0)$ or after $35 \mathrm{~min}(T=35)$. Cultures were then fixed with PFA and stained for TRAP. Adhesion was quantified by counting OCs that were still adherent at $T=35 \mathrm{~min}$ versus the total number of OCs at $T=0$ and expressed as percentage. Results were plotted as the mean percentage of adherent OCs \pm s.D. of triplicate wells for GFP(Ct)- and GFP- $\triangle \mathrm{AF} 2$ (1, 2, and 3)-derived OCs and are representative of two independent experiments.

\section{Transmigration assay}

A transmigrating OC is an OC that had been detached and re-seeded on cell multilayers (for instance, osteoblasts) and that in $12 \mathrm{~h}$ is able to cross the osteoblast multilayers without destroying them and to spread on the plastic substratum beneath the osteoblast. We used the osteoblastic cell line MC3T3-E1, which we cultured for at least 1 week to obtain multilayers of osteoblasts. At the end of the OC differentiation process, OCs derived from $\mathrm{GFP}(\mathrm{Ct})$ and GFP- $\triangle \mathrm{AF} 2(1,2$, and 3$)$ were removed and re-seeded on the top of the multilayers of MC3T3-E1 cells as described previously (Saltel et al. 2006). Primary OCs were also treated with echistatin at $10^{-8} \mathrm{M}$ (Sigma-Aldrich) for $24 \mathrm{~h}$, then seeded on MC3T3 in the presence of echistatin at $10^{-8} \mathrm{M}$ for $12 \mathrm{~h}$. Cells were then fixed after $20 \mathrm{~min}$ or $12 \mathrm{~h}$, then permeabilized with $0.2 \%$ Triton $\mathrm{X}-100$ for $7 \mathrm{~min}$, and stained with Alexa Fluor-546-Phalloidin. OC transmigration efficiency was quantified using a X40 (NA 1.0) Zeiss Plan-Achromat objective by counting the transmigrated OCs versus the total number of OCs and expressed as percentage. Results were plotted as the mean of the number of the transmigrated OCs \pm s.D. of three wells for GFP(Ct)- and GFP- $\triangle \mathrm{AF} 2$ (1, 2, and 3)-derived OCs and as the mean number of the transmigrated OCs \pm S.D. of three wells for non-treated OCs and OCs treated with echistatin. They are representative of three and two independent experiments respectively.

\section{RT-PCR}

Total RNA was extracted with TRIzol reagent from OC derived from spleen cells and RAW cells $(\mathrm{GFP}(\mathrm{Ct})$ and GFP- $\triangle \mathrm{AF} 2(1,2$, and 3)) and from siRNA-transfected RAW cells. Samples of total RNA were reversetranscribed using SuperScript II retrotranscription kit (Invitrogen; Bonnelye et al. 2001). Semi-quantitative PCR was performed for all studied genes. Real-time PCR was carried out to confirm regulated genes found by semi-quantitative PCR. Real-time RT-PCR was carried out by using the LightCycler system (SYBR Green; Qiagen) according to the manufacturer's instructions. PCRs were performed with the primers listed in Table 1, and amplimers were all normalized to corresponding L32 values. Data normalization: in real-time PCR, each replicate average gene's $C_{\mathrm{T}}$ was normalized to the average $C_{\mathrm{T}}$ of L32 by subtracting the average $C_{\mathrm{T}}$ of L32 from each replicate to give the $\Delta C_{\mathrm{T}}$. Results are expressed as $\log ^{-2 \Delta \Delta C_{\mathrm{T}}}$ with $\Delta \Delta C_{\mathrm{T}}$ equivalent to the $\Delta C_{\mathrm{T}}$ of the genes in GFP- $\Delta \mathrm{AF} 2(1,2$, and 3$)$ or siRNA subtracting to the $\Delta C_{\mathrm{T}}$ of the endogenous control (GFP(Ct), Scramble respectively).

\section{Western blotting}

Total proteins were extracted (pools from three $35 \mathrm{~mm}$ dishes for each condition) from RAW cells transfected with $\operatorname{GFP}(\mathrm{Ct})$ or GFP-ERR $\alpha(\mathrm{ERR} \alpha \mathrm{WT}$ or ERR $\alpha \Delta \mathrm{AF} 2)$ constructs according to the standard methods (Ausubel et al. 1996). Western blot analyses were performed using a semidry system. Immunoblotting was performed with anti-GFP (Roche; monoclonal antibody mixture, clones 7.1 and 13.1). Blots were incubated overnight at 
Table 1 Primers and conditions used for PCR

\begin{tabular}{|c|c|c|c|c|}
\hline Gene & Primers & $\begin{array}{l}\text { PCR } \\
\text { cycles }\end{array}$ & Temperature $\left({ }^{\circ} \mathrm{C}\right)$ & References \\
\hline$E R R \alpha$ & $\begin{array}{l}\text { 5': CAGGAAAGTGAATGCCCAGG } \\
3^{\prime}: \text { CTTTGCAGCAAATATACATT }\end{array}$ & 24 & 55 & Bonnelye et al. (2001) \\
\hline L32 & 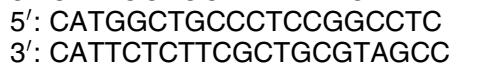 & 24 & 55 & Bonnelye et al. (2001) \\
\hline$E G F P-C 1$ & 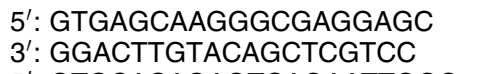 & 25 & 60 & pEGFP-C1 (Clontech) \\
\hline$E R R \gamma$ & $\begin{array}{l}5^{\prime}: \text { ACCATGAATGGCCATCAGAAC } \\
3^{\prime}: \text { ACCAGCTGAGGGTTCAGGTAT }\end{array}$ & 35 & 59 & Cheung et al. (2005) \\
\hline$c$-fms & $\begin{array}{l}5^{\prime}: \text { TGCTGAAGTGGGAGGGAGAG } \\
3^{\prime}: \text { CTGTAGTCTAAGCATCTGTC }\end{array}$ & 24 & 55 & BC043054 \\
\hline OPN & $\begin{array}{l}5^{\prime}: \text { GGTGATAGCTTGGCTTATGG } \\
3^{\prime}: \text { CCTCTTCTTTAGTTGACC }\end{array}$ & 24 & 55 & AF515708 \\
\hline TRAP & $\begin{array}{l}5^{\prime}: \text { TTCCTCCAGGATGGATTCATGG } \\
3^{\prime}: \text { CTGAAGATACTGCAGGTTGTGG }\end{array}$ & 21 & 55 & NM_007388 \\
\hline CTR & $\begin{array}{l}5^{\prime}: \text { CGAACCTGGTCCAACTATACT } \\
3^{\prime}: \text { CCCTGGAAATGAATCAGAGAG }\end{array}$ & 28 & 55 & NM_007588 \\
\hline cytc1 & $\begin{array}{l}5^{\prime}: \text { ATTTCAACCCTTACTTTCCCG } \\
3^{\prime}: \text { CCACTTATGCCGCTTCATGGC }\end{array}$ & 24 & 59 & Herzog et al. (2006) \\
\hline Integrin $\beta 5$ ( $\beta 5)$ & $\begin{array}{l}5^{\prime}: \text { AGATGAGGTGATCACGTGGG } \\
3^{\prime}: \text { GACAGTGTGTGTGGAGATGG }\end{array}$ & 29 & 55 & BC058246 \\
\hline Integrin $\alpha \mathrm{V}(\alpha v)$ & $\begin{array}{l}\text { 5: GCAGATCACCTGCCAGG } \\
\text { 3': CTTGCTCTTCTTGAGGTGG }^{\prime}\end{array}$ & 27 & 55 & NM_008402 \\
\hline
\end{tabular}

room temperature with the polyclonal antibody diluted at $1 / 100$, and binding was detected using HRPconjugated rabbit anti-mice antibodies (1/3000; Bio-Rad Laboratories) and chemiluminescence.

\section{Immunofluorescence}

Cells were fixed in $4 \%$ paraformaldehyde, $\mathrm{pH} 7 \cdot 2$ for $10 \mathrm{~min}$, permeabilized with $0 \cdot 2 \%$ Triton X-100 for $7 \mathrm{~min}$, then incubated with antibodies and AlexaFluor-546-Phalloidin as indicated. Cells were imaged with a confocal Zeiss LSM 510, using a X63 (NA 1.4) Plan Neofluor objective. To prevent contamination between fluorochromes, each channel was imaged sequentially, using the multitrack recording module, before merging. Z-cut pictures were obtained using Zeiss LSM 510 software.

\section{Statistical analysis}

Results for the real-time PCR analysis, the quantification of multinucleated TRAP-positive OCs, podosome belt numbers, adhesion, and transmigration were expressed as mean \pm s.D., and analyzed statistically by one-way ANOVA with the treatment group as variance and by Student's $t$-test with InStat software (version 2.01, GraphPad Software, San Diego, CA, USA). Statistical significance was taken as $P<0 \cdot 05$ (Student's $t$-tests $* P<0 \cdot 05, * * P<0 \cdot 01, * * * P<0 \cdot 001)$.

\section{Results}

\section{$E R R \alpha$ mRNA expression increased during osteoclast differentiation in vitro}

Consistent with our previous findings on the presence of $\mathrm{ERR} \alpha$ protein in multinucleated TRAP-positive cells in rat femur in vivo (Bonnelye et al. 2002), we found, by real-time PCR, ERR $\alpha$ mRNA expressed throughout all the stages of OC differentiation: in primary leukocytes extracted from spleen (day 0), proliferation (day 2), mononucleated progenitor fusion (day 4), and maturation (days 6-8) with significant increases on days 4-8, when multinucleated OCs were starting to form until they reached maturity (Fig. 1A and B). For comparison, mRNA levels for $E R R \beta, E R R \gamma$, and the late $\mathrm{OC}$ differentiation marker CTR were also assessed (Fig. 1A and B). Interestingly and in contrast to $E R R \alpha, E R R \gamma$ mRNA expression decreased dramatically during OC differentiation, while $\operatorname{ERR} \beta$ was not detected. 
A
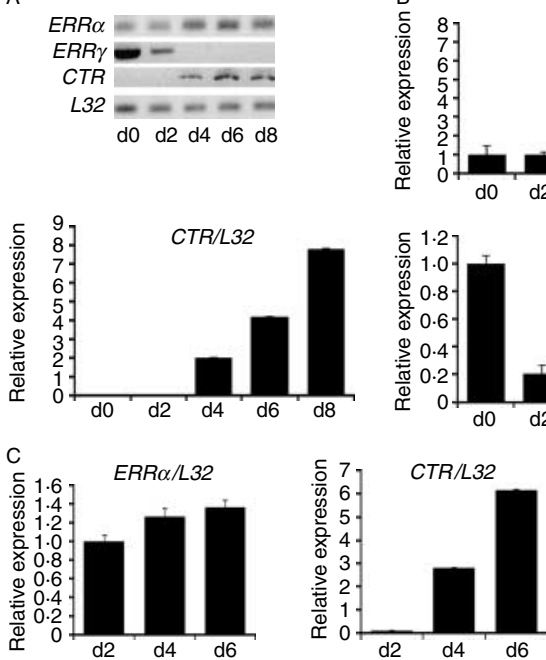

Figure $1 E R R \alpha$ is expressed during OC differentiation. (A and $B$ ) Real-time PCR showed that ERR $\alpha$ is expressed in leukocytes freshly isolated from murine spleen (d0), as well as during osteoclastogenesis (d6-d8). ERR $\alpha$ and ERR $\gamma$ expression were normalized against that of the ribosomal protein gene L32. For comparison, the mRNA level for CTR is also shown. (C) Consistent with primary cells, ERR $\alpha$ is also expressed during OC formation from RAW264.7 cells. d, days in culture.

As previously shown (Bonnelye $e$ t al. 2002), ERR $\alpha$ is also expressed during OC differentiation of the RAW264.7 macrophage cell line, although fold changes in the expression level are less than that observed in primary OC cultures, which is probably due to the fact that RAW264.7 cells are already committed into the macrophage lineage (Fig. 1C). Given its expression in mature OCs, we then checked whether $\operatorname{ERR} \alpha$ was involved in their function.

\section{Down-regulation of ERR $\alpha$ inhibits OPN and integrin B3 expression in RAW264.7-derived osteoclasts}

To check the involvement of ERR $\alpha$ in OC function, we used a truncated version of ERR $\alpha$ lacking the coactivator-binding domain $\mathrm{AF} 2, \mathrm{ERR} \alpha \Delta \mathrm{AF} 2$, which acts as a dominant-negative form of the receptor (Vanacker et al. 1999, Bonnelye et al. 2007). We first confirmed that GFP-ERR $\alpha \Delta$ AF2 acts dominant-negatively on the expression of $O P N$, an ERR $\alpha$ target gene in osteoblasts (Vanacker et al. 1998, Zirngibl et al. 2008, Teyssier et al. 2009), in the MC3T3-E1 cell model (Fig. 2A). GFP-ERR $\alpha \mathrm{WT}$ was also made and transiently transfected with GFP$\mathrm{ERR} \alpha \Delta \mathrm{AF} 2$ into the RAW264.7 macrophage cell line. Protein size was evaluated by western blotting with a GFP antibody, which detected a protein of $\sim 80 \mathrm{kDa}$ resulting from the fusion of the GFP $(30 \mathrm{kDa})$ with the ERR $\alpha W T$ protein (around $53 \mathrm{kDa}$ ) used as a size control (Fig. 2B). As expected, a band of slightly lower molecular weight was detected in GFP-ERR $\alpha$ $\triangle \mathrm{AF} 2$ cells, corresponding to the truncation of the AF2 domain (42 aa; Fig. 2B). Finally, we confirmed the efficacy of GFP-ERR $\alpha \mathrm{WT}$ and GFP-ERR $\alpha \Delta \mathrm{AF} 2$ constructs by luciferase reporter assay with a $(-448$ to $-1 \mathrm{bp})$ BSP promoter fragment ( $p$ GL3BSPLuc), an ERR $\alpha$ target gene in osteoblasts (Bonnelye et al. 2001), in HeLa cells (Fig. 2C). RAW264.7 cells were then stably transfected with the GFP vector alone, which served as control (Ct), and the dominant-negative GFP-ERR $\alpha$ $\Delta \mathrm{AF} 2$ constructs. Three independent RAW-GFP-ERR $\alpha$ $\triangle \mathrm{AF} 2(1,2$, and 3$)$ and one GFP alone clone were obtained, namely GFP- $\triangle \mathrm{AF} 2(1,2$, and 3$)$ and $\mathrm{GFP}(\mathrm{Ct})$ respectively. GFP expression was tested with specific GFP primers after 3 days of culture at the end of the proliferation stage (Fig. 2D and Table 1). GFP mRNA expression was observed in $\mathrm{GFP}(\mathrm{Ct})$ and all the three stable clones GFP- $\triangle \mathrm{AF} 2(1,2$, and 3), with lower GFP expression in GFP- $\triangle \mathrm{AF} 2$ (1, 2, and 3) versus GFP(Ct) cells (Fig. 2D). As expected, a band of $1.7 \mathrm{~kb}$ was amplified with GFP $\left(5^{\prime}\right)$ and ERR $\alpha\left(3^{\prime}\right)$ primers in the RNA isolated from GFP- $\triangle \mathrm{AF} 2$ (1, 2, and 3) cells, whereas no band was detected in $\operatorname{GFP}(\mathrm{Ct})$ cells (Fig. 2D). GFP-ERR $\alpha \Delta$ AF2 expression was estimated to be tenfold less than the expression of the endogenous ERR $\alpha$. Moreover, by using a GFP antibody, $\mathrm{ERR} \alpha$ was localized by immunofluorescence in mature OCs derived from GFP(Ct) and GFP- $\triangle \mathrm{AF} 2$ (1, 2, and 3) cells (Fig. 4C and G). As expected, ERR $\alpha \Delta$ AF2 was detected in both the nucleus and the cytoplasm of GFP$\triangle$ AF2-2-derived OCs (Fig. 4G; similar results were obtained for GFP- $\triangle$ AF2-1 and -3), whereas no GFP was detected in the nucleus of GFP(Ct)-derived OCs (Fig. 4C). Also as expected, the expression level of the ERR $\alpha$ target genes, cytochrome $c-1$ (cytc; Huss et al. 2007) and $O P N$, was significantly reduced in all the three GFP- $\triangle \mathrm{AF} 2$ clones in comparison with $\mathrm{GFP}(\mathrm{Ct})$ cells (Fig. 2E-G), confirming the dominant-negative function of the truncated ERR $\alpha \Delta \mathrm{AF} 2$ construct. Interestingly, the expression of ERR $\gamma$, which was expressed at only undetectable to very low levels in RAW264.7 cells, was markedly increased in two of three GFP- $\triangle \mathrm{AF} 2$ clones in comparison with $\mathrm{GFP}(\mathrm{Ct})$ cells (Fig. 2G).

To determine whether ERR $\alpha$ is involved in OC formation, GFP- $\triangle \mathrm{AF} 2(1,2$, and 3$)$ and $\mathrm{GFP}(\mathrm{Ct})$ cells were differentiated into mature multinucleated OCs in the presence of M-CSF and RANKL. Based on the cell counts after 3 days of culture, at the end of the proliferation stage, reduction of ERR $\alpha$ transactivation capacity had no effect on cell proliferation (data not shown). Concomitantly, the expression of early markers of OC differentiation, such as TRAP, c-fms, and RANKL (data not shown), and of the proliferation marker cyclin D1 was not affected (Fig. 2E and F). Later during differentiation, while the OPN expression was still down-regulated, we found that integrin $\beta 3$ chain expression was also decreased in GFP- $\triangle \mathrm{AF} 2(1,2$, and 3$)$ 
A
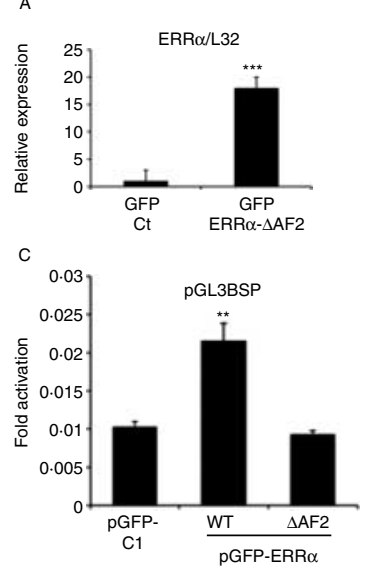

E
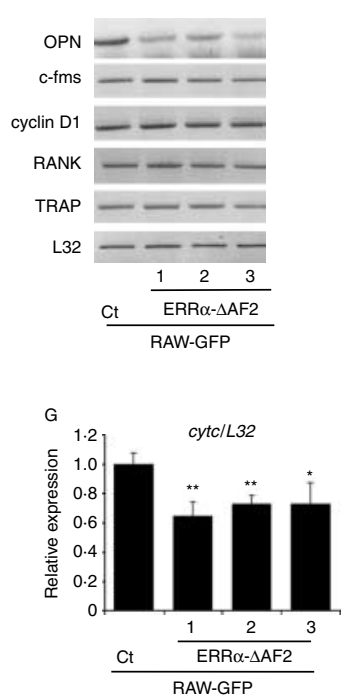
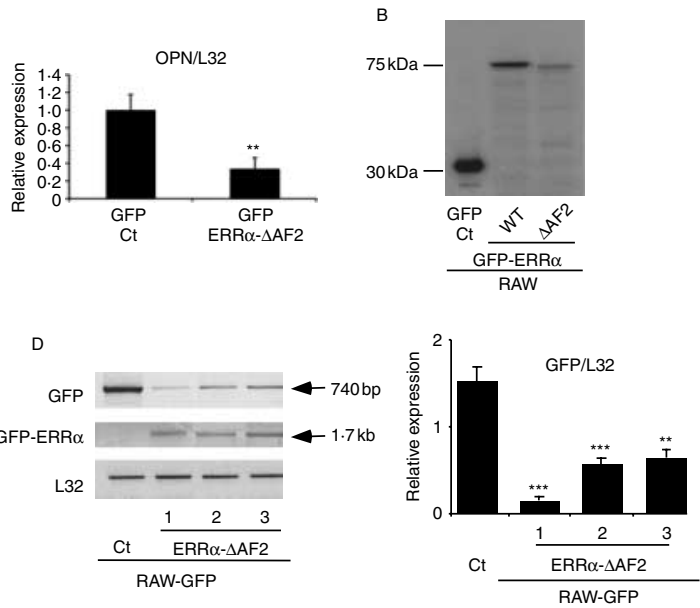

$\mathrm{F}$
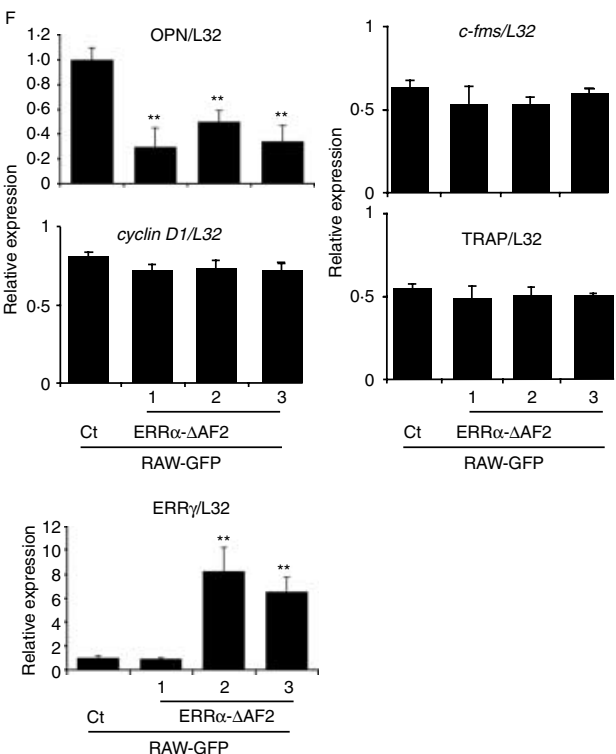

Figure 2 OPN is down-regulated in RAW cells when ERR $\alpha$ function is disrupted. (A) The MC3T3-E1 osteoblastic cell line was transiently transfected with GFP-ERR $\alpha \Delta A F 2$, which down-regulated osteopontin expression, confirming that GFP-ERR $\alpha \Delta$ AF2 acts dominantnegatively (ANOVA, $P=0.0001$ and $P=0.0062$ for GFP-ERR $\alpha \Delta$ AF2 and OPN expression respectively). (B) RAW264.7 cells were transiently transfected, and overexpression of GFP and GFP-ERR $\alpha \mathrm{WT} / \triangle \mathrm{AF} 2$ after transfection was confirmed by western blotting with a monoclonal antibody against GFP. (C) HeLa cells were cotransfected with a luciferase reporter construct containing a ( -448 to $-1 \mathrm{bp}$ ) fragment of the mouse BSP (pGL3 mouse BSP) promoter with either empty pEGFP or GFP-ERR $\alpha \mathrm{WT} / \Delta \mathrm{AF} 2$ vectors. As expected, ERR $\alpha$ up-regulated BSP expression, while the ERR $\alpha \Delta$ AF2 acts dominantnegatively (ANOVA, $P<0.0001$ ). (D) One clone of RAW264.7 cells stably transfected with pEGFP empty plasmid (GFP(Ct)) and three clones stably transfected with pEGFP-ERR $\alpha$ $\triangle \mathrm{AF2}$ (GFP- $\triangle \mathrm{AF2}$ ) were isolated. GFP expression was assessed, after 3 days of culture, by real-time $P C R$ on triplicate samples and normalized against that of the ribosomal protein gene L32. (ANOVA, $P=0.0001$ for GFP in GFP- $\triangle A F 2(1,2$, and 3) versus $\mathrm{GFP}(\mathrm{Ct}))$. (E and $\mathrm{F})$ As expected, OPN expression was decreased (ANOVA, $P=0.0003$ for OPN in GFP- $\triangle A F 2(1,2$, and 3 ) versus GFP(Ct)). mRNA expression of the early markers of OC differentiation (c-fms, TRAP) and proliferation (cyclin D1) was not different in GFP- $\triangle A F 2(1,2$, and 3 ) cells compared with that in GFP(Ct) cells. (G) cytc was downregulated in GFP- $\triangle A F 2(1,2$, and 3) versus GFP(Ct) (ANOVA, $P=0.0096)$. On the other hand, ERR $\gamma$ was expressed in two of the GFP- $\Delta$ AF2 clones $(2,3)$ versus GFP(Ct) (ANOVA, $P<0.0001$ for ERR $\gamma$ ). 
compared with GFP $(\mathrm{Ct})$ cells (Fig. 3A). On the other hand, the expression of $\alpha \mathrm{v}, \beta 1$ and $\beta 5$ integrin chain subunits, c-src, CD44, and Traf6 was not affected (Fig. 3A, and data not shown). Moreover, no differences were observed in the expression of OC factors involved in OC fusion (dendritic cell-specific transmembrane protein DC-STAMP (DCS)) or apoptosis (Bcl2 and Bax) in GFP- $\triangle \mathrm{AF} 2(1,2$, and 3$)$ - versus $\mathrm{GFP}(\mathrm{Ct})$-derived OCs (Fig. 3A).

To confirm the putative functional role of ERR $\alpha$ in $\mathrm{OC}$ as suggested by the results with the dominantnegative form of ERR $\alpha \Delta \mathrm{AF}$, we then checked whether the expression of OPN and integrin $\beta 3$ chain would be similarly altered by the overexpression of
ERR $\alpha \mathrm{WT}$ or by an siRNA directed against ERR $\alpha$. Transient transfection of ERR $\alpha W T$ in RAW264.7 cells at day 3 (transfection efficiency was very low at earlier stages) up-regulated the expression of OPN and integrin $\beta 3$ chain at $48 \mathrm{~h}$ (Fig. 3B). On the other hand, ERR $\alpha$ siRNA elicited a $60 \%$ decrease in the ERR $\alpha$ expression level at day 5 (Fig. 3C). OPN as well as integrin $\beta 3$ expression was also down-regulated in OCs derived from ERR $\alpha$ siRNA-transfected RAW cells compared with control-transfected cells (Sc). Moreover, ERR $\gamma$ expression was higher in ERR $\alpha$ siRNA-treated cells (Fig. 3C), consistent with the results in GFP- $\Delta$ AF2 (1, 2, and 3)-derived OCs (cf. Fig. 2). Taken together, these data suggest that ERR $\alpha$ does not play a role in the
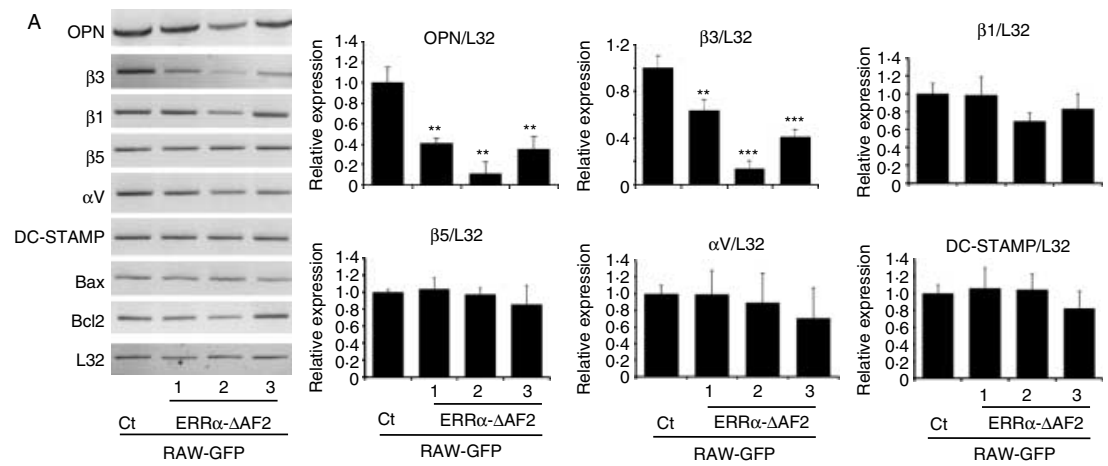

$\mathrm{B}$
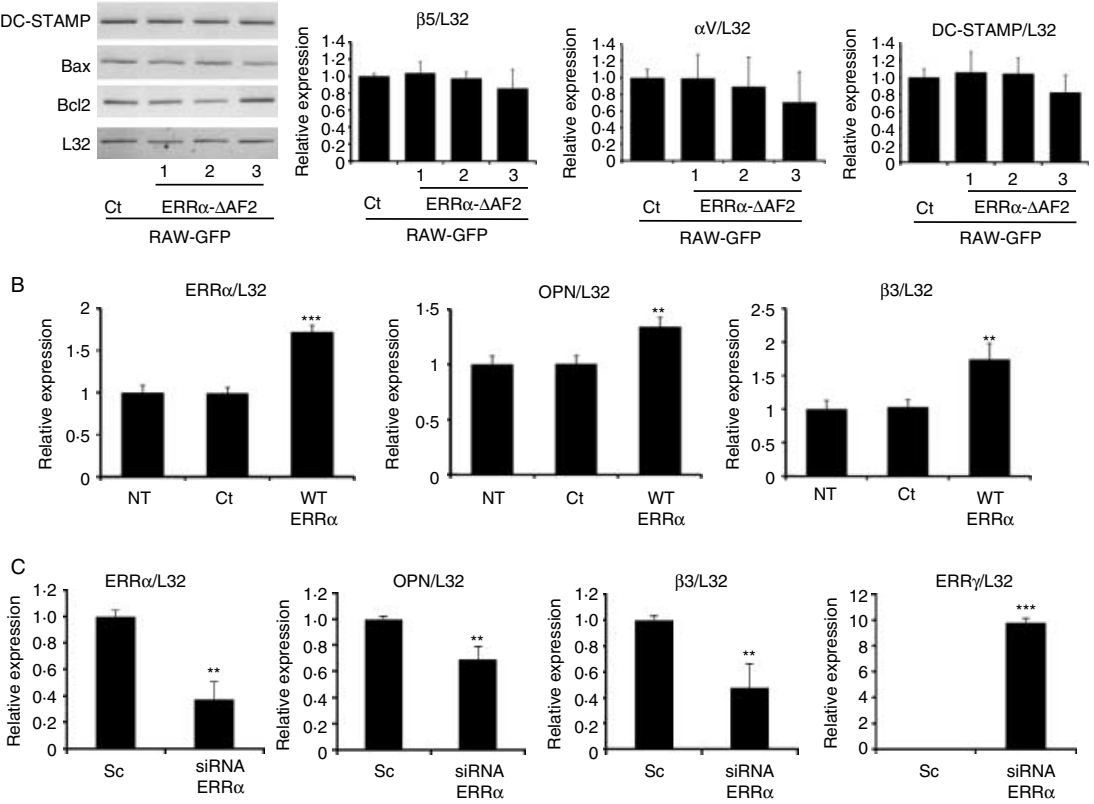

Figure 3 Implication of ERR $\alpha$ in integrin $\beta 3$ expression in GFP- $\triangle$ AF2-derived OCs (A) Total RNA was extracted from GFP(Ct)- and GFP- $\triangle$ AF2 (1, 2, and 3)-derived OCs after 6 days of culture, and real-time PCR was performed on triplicate samples by using primers specific for several genes involved in OCs spreading. Quantification shows a statistically significant decrease in $\beta 3$ integrin and OPN in GFP- $\triangle \mathrm{AF} 2(1,2$, and 3) (ANOVA, $P=0.0002$; ANOVA, $P=0.0001, \Delta \mathrm{AF} 2(1,2$, and 3$)$ versus $C_{\mathrm{t}}$ for OPN and $\beta 3$ respectively). Markers for adhesion (integrin subunits $\alpha \mathrm{v}, \beta 1$, and $\beta 5$ ), OC cell-cell fusion (DC-STAMP) were not modified. (B) Overexpression of ERR $\alpha$ was induced by transient transfection of ERR $\alpha$ WT in RAW264.7 cells. Quantification shows a statistically significant increase in OPN and $\beta 3$ integrin expression in ERR $\alpha$ WT-transfected cells (ANOVA, $P=0.0001$; ANOVA,

$P=0.0011, P=0.0023$, for $\mathrm{ERR} \alpha$, OPN, and $\beta 3$ respectively). (C) siRNA directed against ERR $\alpha$ or a control scrambled siRNA (Sc) was transiently transfected into RAW264.7 cells. As expected, ERR $\alpha$ expression was down-regulated after transfection with ERR $\alpha$ siRNA (ANOVA, $P=0.0015)$. Concomitantly, OPN and integrin 33 expression was decreased (ANOVA, $P=0.0053, P=0.077$ for OPN and integrin $\beta 3$ respectively). On the other hand, ERR $\gamma$ was dramatically expressed in ERR $\alpha$ siRNA-transfected cells versus Sc (ANOVA, $P=0.0004$ for ERR $\gamma$ ). 
proliferation/differentiation process of macrophages to OCs, but may be involved in their adhesion, spreading, or migration activities.

\section{Disruption of ERR $\alpha$ function inhibits OC spreading and formation of podosome belts in RAW264.7- derived osteoclasts}

To unravel the function of ERR $\alpha$ in OCs, GFP- $\Delta \mathrm{AF} 2$ $(1,2$, and 3) and GFP(Ct) RAW cells were differentiated into mature multinucleated OCs in the presence of
M-CSF and RANKL. After 6 days, no difference was observed between the number of large multinucleated TRAP-positive OCs and between the nuclei number in GFP- $\triangle \mathrm{AF} 2$ (1, 2, and 3) versus GFP(Ct) cells, suggesting that $\mathrm{ERR} \alpha$ does not affect OC differentiation from macrophages (Fig. 4I-J). However, TRAP-positive GFP- $\Delta$ AF2-2-derived OCs (Fig. 4E) appeared less spread than TRAP-positive GFP(Ct)-derived OCs (Fig. 4A). This morphological difference was well correlated to their actin cytoskeletal organization. Indeed, well spread GFP(Ct)-derived OCs exhibited a typical podosome belt (Fig. 4B, D and K), whereas in less spread
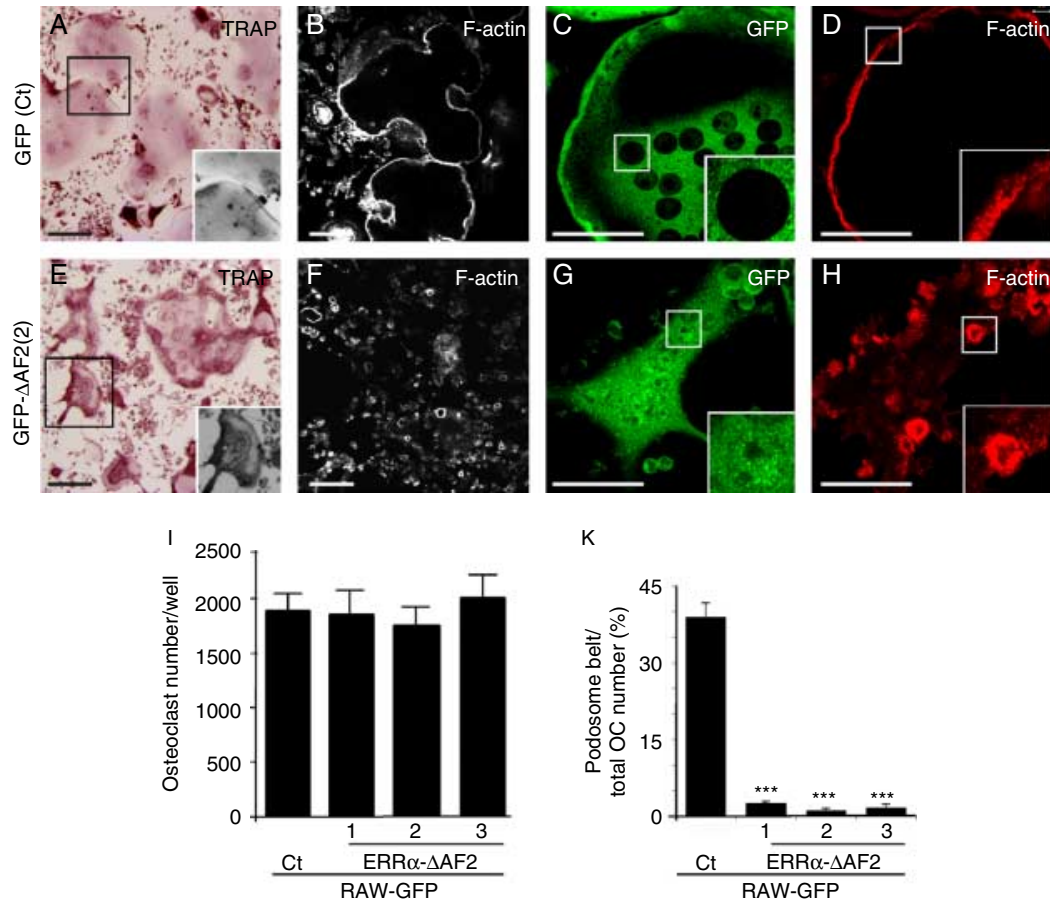

$\mathrm{K}$
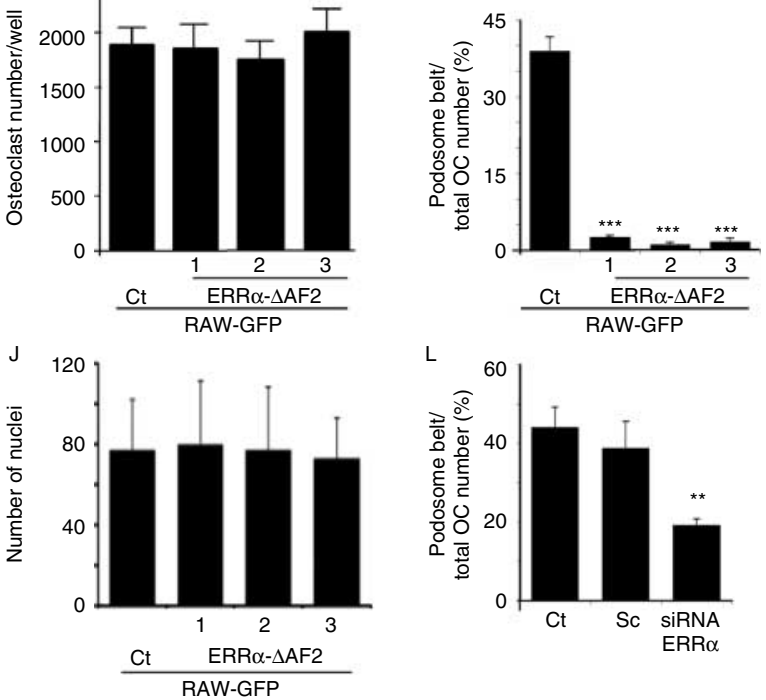

Figure 4 Involvement of ERR $\alpha$ in OC spreading. RAW-GFP(Ct) and RAW-GFP- $\triangle A F 2$ $(1,2$, and 3$)$ cells were differentiated for 6 days in culture in the presence of RANKL. (A and E) After TRAP staining, the total number of OCs (I) were quantified. (J) After TRAP staining, the number of nuclei per hundred OCs for each clone was quantified. Podosome belt formation was evaluated after actin staining of (K) GFP(Ct)- and GFP- $\Delta A F 2(1,2$, and 3)-derived OCs (ANOVA, $P=0.0001$ ), or (L) ERR $\alpha$ siRNA or Sc-transfected RAW cell-derived OCs versus non-transfected cells $\left(C_{\mathrm{t}}\right)$ (ANOVA; $\left.P=0 \cdot 0019\right)$. (C and $\mathrm{G}$ ) Immunolabeling for GFP shows nuclear and cytoplasm location for ERR $\alpha$. Staining using rhodamine-phalloidin ( $\mathrm{B}, \mathrm{D}, \mathrm{F}$, and $\mathrm{H}$ ) showed the actin cytoskeletal organization of GFP- $\triangle A F 2(1,2$, and 3 ) into actin-containing rings ( $F$ and $H)$, while $G F P(C t)$-derived OCs exhibited podosome belts $(B$ and $D)$. Bar $=20 \mu \mathrm{m}(A-H)$. Full color version of this figure available via http://dx.doi.org/10.1677/JME-10-0024. 
GFP- $\triangle \mathrm{AF} 2$ (1, 2, and 3)-derived OCs, podosomes were organized as clusters or small rings (Fig. $4 \mathrm{~F}, \mathrm{H}$ and $\mathrm{K}$ ). Similar results were obtained in RAW cells transfected with $\mathrm{ERR} \alpha$ siRNA versus Sc siRNA or non-transfected cells (Fig. 4L). Together with the down-regulation of both OPN and $\beta 3$ integrin chain, these latter results strongly suggest that $\mathrm{ERR} \alpha$ is involved in OC adhesion.

\section{Disruption of $O C$ adhesion and transmigration: implication of integrin $\beta 3$ in GFP- $\triangle$ AF2-derived OC}

Down-regulation of $\beta 3$ expression in GFP- $\triangle$ AF2-2derived OCs at day 6 (Fig. 3A) was confirmed by immunofluorescence using an antibody against integrin $\beta 3$ (Fig. 5A and D). As expected, intense $\beta 3$ integrin subunit staining was localized around the actin core of podosomes organized in a belt in $\operatorname{GFP}(\mathrm{Ct})$ derived OCs at day 6 (Fig. 5A and B, see merged in Fig. 4C). In contrast, labeling for $\beta 3$ integrin subunit protein was diffusely distributed within GFP- $\triangle$ AF2-2derived OCs at day 6 (Fig. 5D and E, see merged in F). Since we, and others, have shown the importance of c-src in integrin signaling for actin organization, we looked for phosphorylated c-src localization in OCs expressing the dominant-negative form of $E R R \alpha$. Whereas phosphorylated c-src was distributed around the podosome belt in $\mathrm{GFP}(\mathrm{Ct})$-derived OCs on day 6 (Fig. 5G and $\mathrm{H}$, see merged in I), it was diffusely
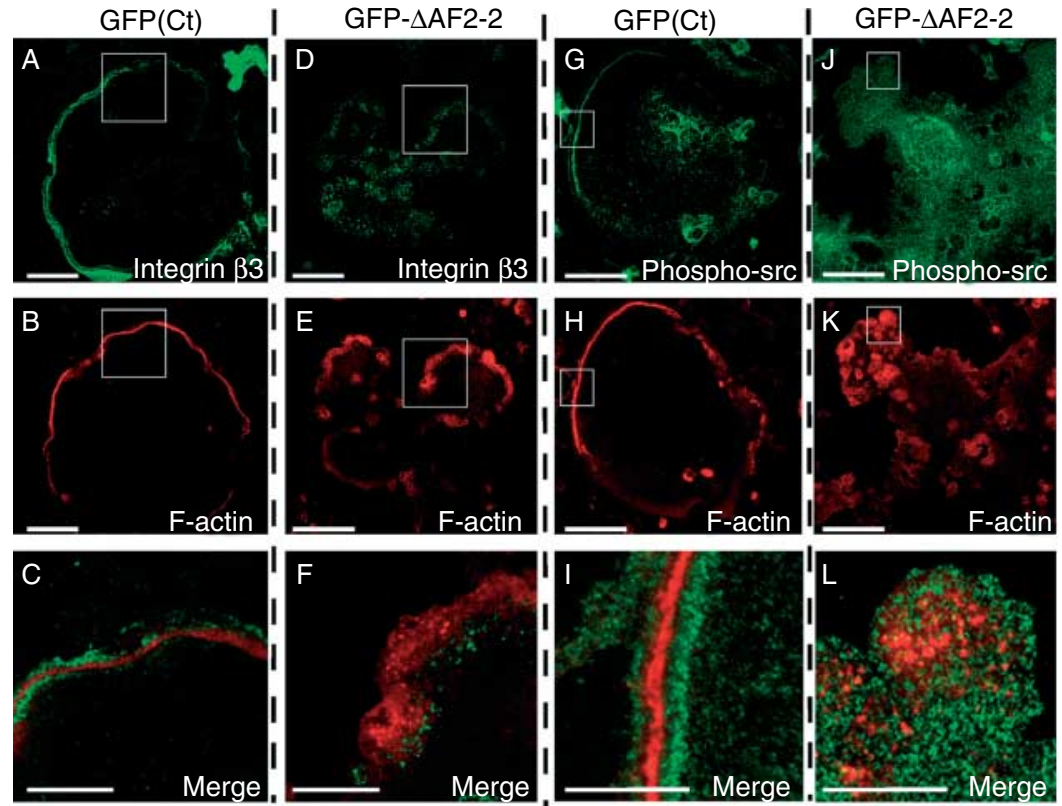

$\mathrm{M}$

$\mathrm{N}$
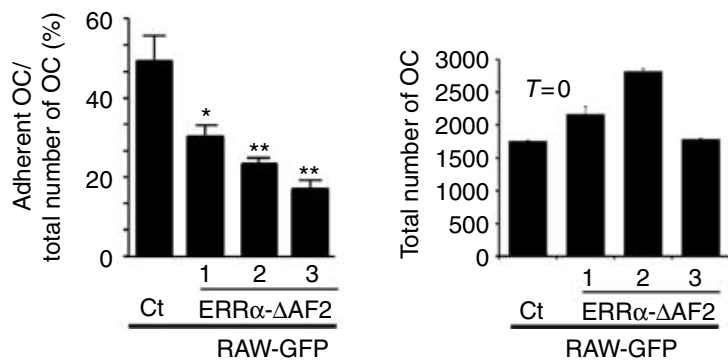

Figure 5 Integrin subunit $\beta 3$ expression and localization are altered in GFP- $\triangle$ AF2derived OCs. (A-L) $\beta 3$ integrin subunit (A, D, C, and $F$ in green), phosphorylated $C$-src $(G, J, I$, and $L$ in green), and actin (B, C, E, F, H, I, K, and $L$ in red) were immunostained in control (A-C; G-I) and in GFP- $\triangle A F 2-2$-derived OCs (D-F; J-L). Whereas control OC formed typical podosome belts with actin dots surrounded by $\beta 3$ integrin and phosphorylated c-src (A-C; G-I), podosomes of GFP- $\Delta$ AF2-2-derived OCs were disorganized with mislocalized $\beta 3$ integrin and phosphorylated c-src (D-F; J-L). Merged images of the closeup areas of actin, $\beta 3$, and phosphorylated c-src respectively are also shown (C, F, I, and L). Bar $=20 \mu \mathrm{m}$. (M) Adhesion ability was also evaluated (ANOVA, $P=0.0001 ; \Delta$ AF2 $(1,2$, and 3$)$ ), while $(\mathrm{N})$ OC viability was evaluated by counting the total number of OCs used in the adhesion test at $T=0$. 
localized in GFP- $\triangle$ AF2-2 cells (Fig. 5J and K, see merged in L). Similarly, vinculin localization was disrupted in GFP- $\triangle$ AF2 cells (data not shown) compared with GFP $(\mathrm{Ct})$-derived OCs at day 6 . These results suggest that disturbing $E R R \alpha$ function impairs a signaling pathway linked to OPN, integrin $\beta 3$, activated c-src, and actin organization. Moreover, and in agreement with the decrease in mature OC spreading, we observed a decrease in OC adhesion in GFP- $\triangle \mathrm{AF} 2$ (1, 2, and 3)derived OCs compared with GFP(Ct)-derived cells (by $40 \%$ in $\triangle \mathrm{AF} 2-1,50 \%$ in $\triangle \mathrm{AF} 2-2$, and $68 \%$ in $\triangle \mathrm{AF} 2-3$ compared with GFP(Ct); Fig. 5M). It was observed that the differences in OC viability, as reflected by $\mathrm{OC}$ number, cannot account for the differences in spreading between GFP(Ct)- and GFP- $\triangle \mathrm{AF} 2$ (1, 2, and 3)derived OCs $(T=0$; Fig. $5 \mathrm{~N})$.

To address further the consequences of disrupting the actin structure due to the expression of a dominantnegative form of ERR $\alpha$ in OCs, we then checked whether OC transmigration was affected (Saltel et al. 2006). To this end, mature GFP- $\triangle \mathrm{AF} 2$ (1, 2, and 3)- and GFP $(\mathrm{Ct})$-derived OCs were seeded onto confluent osteoblastic MC3T3-E1 cells. After $20 \mathrm{~min}$, large rounded OCs (identified by GFP expression in green, white arrows) derived from GFP- $\triangle \mathrm{AF} 2(1,2$, and 3) (Fig. 6G, see Z-cut section E) and GFP(Ct) (Fig. 6C, see Z-cut section A) cells were localized on the top of confluent osteoblastic MC3T3-E1 cell layers (red, see white asterisk). After $12 \mathrm{~h}$, OCs derived from GFP(Ct) cells were well spread and attached to the substratum beneath the osteoblasts (Fig. 6D, and Z-cut section in B), showing that they had transmigrated through the MC3T3-E1 cell layers. In contrast, after $12 \mathrm{~h}$ of culture, OCs derived from GFP- $\triangle$ AF2-2 cells appeared 'frozen' on the top of the MC3T3-E1 cell layers where they maintained a rounded shape (Fig. 6H, see GFP-positive OCs (white arrow) and Z-cut section in Fig. 6F). Similar observations were obtained for GFP- $\Delta$ AF2 clones 1 and 3
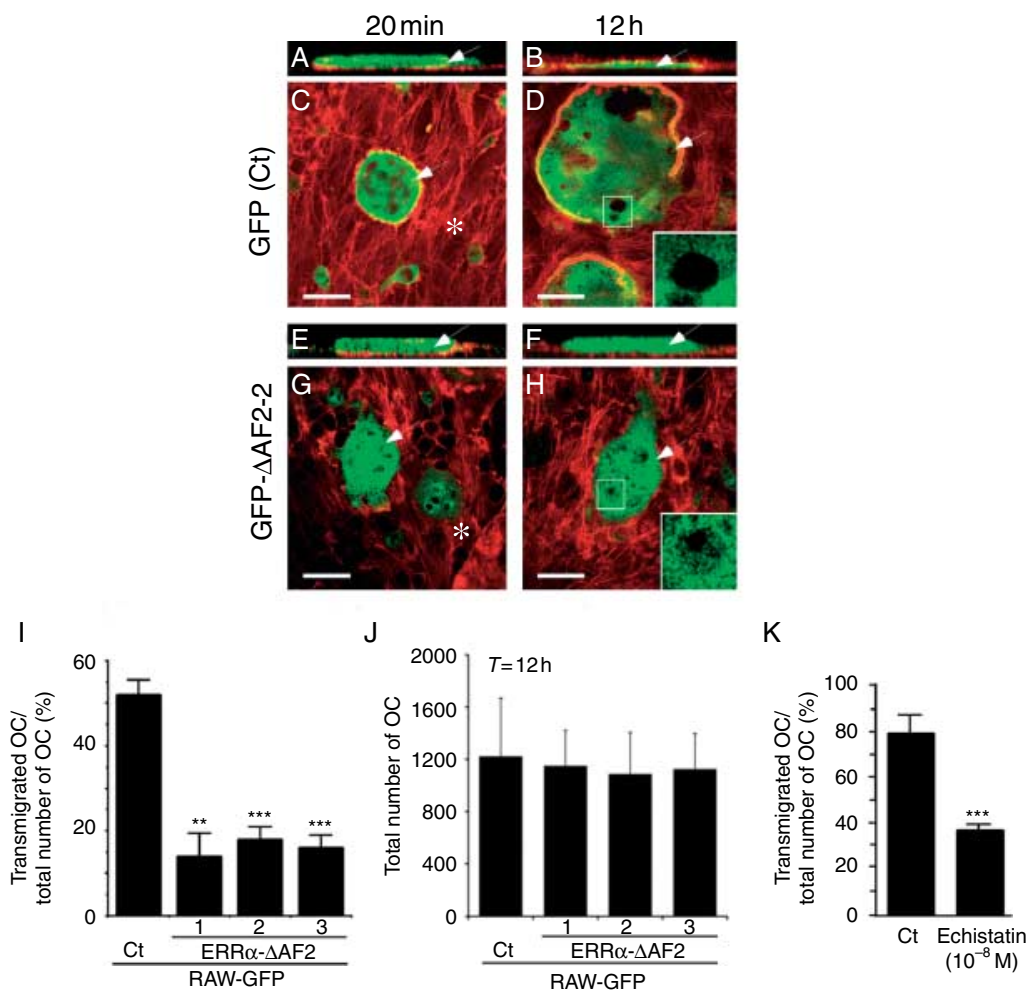

Figure 6 Transmigration ability is decreased in GFP- $\triangle$ AF2-derived OCs. GFP(Ct) (A-D, green) and GFP- $\triangle$ AF2-2-derived OCs $(E-H$, green) were seeded on the top of MC3T3-E1 cells (red). Z-cut sections show that 20 min after seeding, OCs were lying on the top of MC3T3-E1 cells (A and E). Control OCs had transmigrated down through the osteoblast layer $12 \mathrm{~h}$ after seeding (B), whereas GFP- $\triangle A F 2$-derived OCs had not (F). (I) Inhibition of transmigration in GFP- $\triangle A F 2$ (1, 2, and 3)- versus GFP(Ct)-derived OCs was quantified. (J) OC viability was evaluated by counting the total number of OCs used in the transmigration assay. $(\mathrm{K})$ Inhibition of transmigration was also observed when mature OCs were treated with echistatin. (I and K) Results represent the mean (\%) of the transmigrated OC/total OC number \pm s.D. for triplicate determinations. (I) ANOVA; $P=0.001$. (K) ANOVA; $P=0.0004$. $B a r=20 \mu \mathrm{m}$. 
(data not shown). Quantification of transmigrated OCs versus non-transmigrated OCs confirmed a significant decrease $(72 \%$ in $\triangle \mathrm{AF} 2-1,63 \%$ in $\triangle \mathrm{AF} 2-2$, and $67 \%$ in $\triangle \mathrm{AF} 2-3$ ) in the transmigrated $\mathrm{OC}$ numbers in GFP$\triangle \mathrm{AF} 2$ (1, 2, and 3)- compared with $\operatorname{GFP}(\mathrm{Ct})$-derived OCs (Fig. 6I). Viability of the transmigrated GFP(Ct)and GFP- $\triangle \mathrm{AF} 2(1,2$, and 3)-derived OCs is equivalent (total OC number at $T=12 \mathrm{~h}$; Fig $6 \mathrm{~J}$ ). Interestingly, the inhibition of transmigration observed with the knockdown of ERR $\alpha$ correlated with that observed after blocking integrins with echistatin, an RGD disintegrin, in primary OCs re-seeded onto confluent osteoblastic MC3T3-E1 cells (Fig. 6K).

\section{Discussion}

We report that the overexpression or knockdown of $\mathrm{ERR} \alpha$ function in the RAW264.7 macrophage cell line either by stable transfection of a dominant-negative form of ERR $\alpha$, GFP-ERR $\alpha \Delta \mathrm{AF} 2$ or by ERR $\alpha$ siRNA leads to modulation of the expression of OPN and $\beta 3$ integrin subunit with concomitant actin cytoskeletal disorganization in the podosome belt, reduced adhesion on tissue culture plastic or glass, and reduced transmigration activity. Although ERR $\alpha$ knockout mice and cells are now available, our work was initiated when these were not available, and both our stable and transient knockdown approaches gave comparable and highly reproducible results. It is therefore not clear why no detectable alteration in the OC parameters was observed in ERR $\alpha$ knockout mice (Delhon et al. 2009, Teyssier et al. 2009), but it seems likely that compensatory mechanisms involving ERR $\gamma$ may be operating, since we found that ERR $\gamma$ is expressed in RAW264.7 cells when ERR $\alpha$ function is disrupted.

The molecular basis for the ERR $\alpha$ effect on cell mobility is of interest because $O P N$, which is expressed in several motile cell types including OCs and many tumor cell lines (Standal et al. 2004), has been described as a target gene of $\operatorname{ERR} \alpha$ in promoter reporter assays in vitro (Vanacker et al. 1998, Zirngibl et al. 2008). OPN is involved in cell adhesion and migration and promotes cell attachment to bone (Denhardt \& Noda 1998). Adhesion receptors $\alpha \mathrm{v} \beta 1$, $\alpha_{v} \beta 3$, and $\alpha_{v} \beta 5$ integrins and the hyaluronan receptor (CD44) are all receptors for OPN, and their interactions are crucial for OC adhesion and motility (McHugh et al. 2000, Chellaiah \& Hruska 2003). Notably, OPN is known to stimulate glass-adherent OC migration through the $\alpha v \beta 3$ integrin-induced activation of c-src and actin cytoskeletal reorganization into podosome belts (Duong et al. 1998). While $\alpha \mathrm{v}, \beta 1$, and $\beta 5$ integrin subunits and CD44 were not affected by the changes in ERR $\alpha$ activity, the expression of the $\beta 3$ integrin subunit was down-regulated in siRNA and
GFP- $\triangle$ AF2-derived OCs. In addition, more detailed studies in GFP- $\triangle \mathrm{AF} 2$-derived OCs showed that the disruption of podosome belt formation was accompanied by an aberrant/diffuse distribution of the $\beta 3$ integrin subunit, activated c-src, and vinculin. Thus, it is likely that the inhibition of adhesion and disruption of the podosome belt observed in GFP- $\Delta$ AF2-derived OCs is a consequence of the reduced expression of both OPN and $\beta 3$ that consequently induced the disrupted localization of activated c-src. Moreover, although neither of the latter is known to be involved in OC transmigration, the fact that $\alpha \mathrm{v} \beta 3$ is involved in monocyte transendothelial migration, that echistatin, an RGD disintegrin, induces a decrease in $O C$ transmigration, and that c-src is involved in OC transmigration through MC3T3-E1 cell layers suggests that the $\beta 3$ integrin subunit may be involved in OC transmigration (Weerasinghe et al. 1998, Saltel et al. 2006). Indeed, in the presence of PP2, a c-src inhibitor, OCs maintain a rounded shape and sit on the top of MC3T3-E1 cell layers (Saltel et al. 2006) in a manner similar to GFP- $\triangle$ AF2-derived OCs. These data suggest that the disruption of activated c-src localization may, at least in part, be due to down-regulated OPN and/or integrin subunit $\beta 3$ expression and may be responsible for the inhibition of transmigration in GFP- $\triangle$ AF2-derived OCs.

We have previously shown that ERR $\alpha$ positively regulates osteoblast formation in rat calvarial cells in vitro, acting at multiple developmental times to regulate both proliferation and differentiation events (Bonnelye et al. 2001). However, more recent data with $E R R \alpha$ knockout mice and with human bone marrow stromal cells suggest that ERR $\alpha$ may play a negative regulatory role in other models or at other developmental times (Delhon et al. 2009, Teyssier et al. 2009). Further complicating the issue, one study suggests that an ESRRA gene regulatory variant leading to increased $\mathrm{ERR} \alpha$ expression is associated with increased bone mineral density in premenopausal women (Laflamme et al. 2005), although a recent report has failed to confirm the observation (Giroux et al. 2008). Such apparently complex and multiphasic activities, complicated by potential compensatory mechanisms involving other ERR family members, are in keeping with our current data showing that down-regulation of ERR $\alpha$ decreases OC transmigration, suggesting that ERR $\alpha$ may positively regulate OC migration. Altogether, the data suggest that ERR $\alpha$ may contribute to bone homeostasis not only through effects on osteoblast lineage cells but also on OCs.

ERR $\alpha$ expression in other highly motile cells such as dendritic cells and macrophages (Sonoda et al. 2007, Bonnelye et al. 2008) supports a role for ERR $\alpha$ in inflammatory diseases associated with osteoclastic bone degradation such as rheumatoid arthritis and other 
diseases, where $\alpha \mathrm{v} \beta 3$ and OPN are also implicated (Wilder 2002, Yumoto et al. 2002). In this regard, recently, and similarly to our data on OC migration, siRNA-mediated knockdown of ERR $\alpha$ in the highly aggressive breast carcinoma MDA-231 cell line resulted in a dramatic decrease in their migration (Stein $e t$ al. 2008). We thus hypothesize that the ERR $\alpha$-regulated OPN and integrin subunit $\beta 3$ pathway that we described here may also be operative in cancer cells.

In conclusion, ERR $\alpha$ is expressed in OCs where it regulates the expression of OPN and integrin subunit $\beta 3$, and plays a role in the spreading, organization, and/or stabilization of podosomes at the cell periphery, as well as in the adhesion and transmigration in a RAW cell culture model in vitro. Further understanding of the mechanisms by which ERR $\alpha$ modulates migration in the normal development and disease is required. In the meantime, our data suggest that the regulation of ERR $\alpha$ activity may provide a new therapeutic strategy for inflammatory and bone diseases associated with an imbalance in bone remodeling due to excessive OC resorption.

\section{Declaration of interest}

The authors declare that there is no conflict of interest that could be perceived as prejudicing the impartiality of the research reported.

\section{Funding}

This work was supported by the 'Ligue Contre le Cancer' (Rhône, Drome), ARC and CNRS, and the Canadian Institutes of Health Research (CIHR FRN 88104 to JEA). AC was the recipient of an 'allocation couplée' grant from ENS Lyon.

\section{Acknowledgements}

We are very grateful to Fabienne Simian and Claire Lionnet from PLATIM (IFR 128 Lyon Biosciences) for their kind help with imaging experiments, and to Olivier Destaing for helpful discussions.

\section{References}

Ausubel FM, Brent R, Kinston RE, Moore DD, Seidman JG, Smith JA \& Struhl K 1996 Current Protocols in Molecular Biology, vol 1, unit 10.8. New York, NY: John Wiley \& Sons.

Benoit G, Cooney A, Giguere V, Ingraham H, Lazar M, Muscat G, Perlmann T, Renaud JP, Schwabe J, Sladek F et al. 2006 International Union of Pharmacology. LXVI. Orphan nuclear receptors. Pharmacological Reviews 58 798-836. (doi:10.1124/pr.58.4.10)

Bonnelye E, Merdad L, Kung V \& Aubin JE 2001 The orphan nuclear estrogen receptor-related receptor (ERR) is expressed throughout osteoblast differentiation and regulates bone formation in vitro. Journal of Cell Biology 153 971-983. (doi:10.1083/jcb.153.5.971)
Bonnelye E, Kung V, Laplace C, Galson DL \& Aubin JE 2002 Estrogen receptor-related receptor $\alpha$ impinges on the estrogen axis in bone: potential function in osteoporosis. Endocrinology 143 3658-3670. (doi:10.1210/en.2002-220095)

Bonnelye E, Zirngibl RA, Jurdic P \& Aubin JE 2007 The orphan nuclear estrogen receptor-related receptor- $\alpha$ regulates cartilage formation in vitro: implication of Sox9. Endocrinology 148 1195-1205. (doi:10.1210/en.2006-0962)

Bonnelye E, Laurin N, Jurdic P, Hart DA \& Aubin JE 2008 Estrogen receptor-related receptor- $\alpha$ (ERR- $\alpha$ ) is dysregulated in inflammatory arthritis. Rheumatology 47 1785-1791. (doi:10.1093/rheumatology/ken368)

Boyle WJ, Simonet WS \& Lacey DL 2003 Osteoclast differentiation and activation. Nature 423 337-342. (doi:10.1038/nature01658)

Chabadel A, Banon-Rodriguez I, Cluet D, Rudkin BB, Wehrle-Haller B, Genot E, Jurdic P, Anton IM \& Saltel F 2007 CD44 and $\beta 3$ integrin organize two functionally distinct actin-based domains in osteoclasts. Molecular Biology of the Cell 18 4899-4910. (doi:10.1091/ mbc.E07-04-0378)

Chellaiah MA \& Hruska KA 2003 The integrin $\alpha(v) \beta(3)$ and CD44 regulate the actions of osteopontin on osteoclast motility. Calcified Tissue International 72 197-205. (doi:10.1007/s00223-002-1025-6)

Cheung CP, Yu S, Wong KB, Chan LW, Lai FM, Wang X, Suetsugi M, Chen S \& Chan FL 2005 Expression and functional study of estrogen receptor-related receptors in human prostatic cells and tissues. Journal of Clinical Endocrinology and Metabolism 90 1830-1844. (doi:10.1210/jc.2004-1421)

Delaisse JM, Andersen TL, Engsig MT, Henriksen K, Troen T \& Blavier L 2003 Matrix metalloproteinases (MMP) and cathepsin K contribute differently to osteoclastic activities. Microscopy Research and Technique 61 504-513. (doi:10.1002/jemt.10374)

Delhon I, Gutzwiller S, Morvan F, Rangwala S, Wyder L, Evans G, Studer A, Kneissel M \& Fournier B 2009 Absence of estrogen receptor related $\alpha$ increases osteoblastic differentiation and cancellous bone mineral density. Endocrinology $1504463-4472$. (doi:10.1210/en.2009-0121)

Denhardt DT \& Noda M 1998 Osteopontin expression and function: role in bone remodeling. Journal of Cellular Biochemistry. Supplement 30-31 92-102. (doi:10.1002/(SICI) 1097-4644(1998)72:30/ $31+<92::$ AID-JCB13 $>3.0$. CO;2-A)

Destaing O, Saltel F, Geminard JC, Jurdic P \& Bard F 2003 Podosomes display actin turnover and dynamic self-organization in osteoclasts expressing actin-green fluorescent protein. Molecular Biology of the Cell 14 407-416. (doi:10.1091/mbc.E02-07-0389)

Domon T, Yamazaki Y, Fukui A, Ohnishi Y, Takahashi S, Yamamoto T \& Wakita M 2002 Three-dimensional distribution of the clear zone of migrating osteoclasts on dentin slices in vitro. Tissue and Cell 34 326-336. (doi:10.1016/S0040816602000137)

Duong LT, Lakkakorpi PT, Nakamura I, Machwate M, Nagy RM \& Rodan GA 1998 PYK2 in osteoclasts is an adhesion kinase, localized in the sealing zone, activated by ligation of $\alpha(\mathrm{v}) \beta 3$ integrin, and phosphorylated by src kinase. Journal of Clinical Investigation 102 881-892. (doi:10.1172/JCI3212)

Gennari L, De Paola V, Merlotti D, Martini G \& Nuti R 2007 Steroid hormone receptor gene polymorphisms and osteoporosis: a pharmacogenomic review. Expert Opinion on Pharmacotherapy 8 537-553. (doi:10.1517/14656566.8.5.537)

Giguere V, Yang N, Segui P \& Evans RM 1988 Identification of a new class of steroid hormone receptors. Nature 331 91-94. (doi:10. 1038/331091a0)

Giroux S, Elfassihi L, Cole DE \& Rousseau F 2008 Replication of associations between LRP5 and ESRRA variants and bone density in premenopausal women. Osteoporosis International 19 1769-1775. (doi:10.1007/s00198-008-0617-z)

Green S, Walter P, Kumar V, Krust A, Bornert JM, Argos P \& Chambon P 1986 Human oestrogen receptor cDNA: sequence, expression and homology to v-erb-A. Nature 320 134-139. (doi:10.1038/320134a0) 
Greschik H, Wurtz JM, Sanglier S, Bourguet W, van Dorsselaer A, Moras D \& Renaud JP 2002 Structural and functional evidence for ligand-independent transcriptional activation by the estrogenrelated receptor 3. Molecular Cell 9 303-313. (doi:10.1016/ S1097-2765(02) 00444-6)

Herzog B, Cardenas J, Hall RK, Villena JA, Budge PJ, Giguère V, Granner DK \& Kralli A 2006 Estrogen-related receptor alpha is a repressor of phosphoenolpyruvate carboxykinase gene transcription. Journal of Biological Chemistry 281 99-106. (doi:10.1074/jbc. M509276200)

Huss JM, Imahashi K, Dufour CR, Weinheimer CJ, Courtois M, Kovacs A, Giguere V, Murphy E \& Kelly DP 2007 The nuclear receptor ERR $\alpha$ is required for the bioenergetic and functional adaptation to cardiac pressure overload. Cell Metabolism 6 25-37. (doi:10.1016/j.cmet.2007.06.005)

Jurdic P, Saltel F, Chabadel A \& Destaing O 2006 Podosome and sealing zone: specificity of the osteoclast model. European Journal of Cell Biology 85 195-202. (doi:10.1016/j.ejcb.2005.09.008)

Kallen J, Schlaeppi JM, Bitsch F, Filipuzzi I, Schilb A, Riou V, Graham A, Strauss A, Geiser M \& Fournier B 2004 Evidence for ligandindependent transcriptional activation of the human estrogenrelated receptor $\alpha(E R R \alpha)$ : crystal structure of ERR $\alpha$ ligand binding domain in complex with peroxisome proliferator-activated receptor coactivator-1 $\alpha$. Journal of Biological Chemistry 279 49330-49337. (doi:10.1074/jbc.M407999200)

Kuiper GG, Enmark E, Pelto-Huikko M, Nilsson S \& Gustafsson JA 1996 Cloning of a novel receptor expressed in rat prostate and ovary. PNAS 93 5925-5930. (doi:10.1073/pnas.93.12.5925)

Laflamme N, Giroux S, Loredo-Osti JC, Elfassihi L, Dodin S, Blanchet C, Morgan K, Giguere V \& Rousseau F 2005 A frequent regulatory variant of the estrogen-related receptor $\alpha$ gene associated with BMD in French-Canadian premenopausal women. Journal of Bone and Mineral Research 20 938-944. (doi:10.1359/JBMR.050203)

Luo J, Sladek R, Carrier J, Bader JA, Richard D \& Giguere V 2003 Reduced fat mass in mice lacking orphan nuclear receptor estrogen-related receptor $\alpha$. Molecular and Cellular Biology 23 7947-7956. (doi:10.1128/MCB.23.22.7947-7956.2003)

McHugh KP, Hodivala-Dilke K, Zheng MH, Namba N, Lam J, Novack D, Feng X, Ross FP, Hynes RO \& Teitelbaum SL 2000 Mice lacking $\beta 3$ integrins are osteosclerotic because of dysfunctional osteoclasts. Journal of Clinical Investigation 105 433-440. (doi:10.1172/JCI8905)

Saltel F, Destaing O, Bard F, Eichert D \& Jurdic P 2004 Apatitemediated actin dynamics in resorbing osteoclasts. Molecular Biology of the Cell 15 5231-5241. (doi:10.1091/mbc.E04-06-0522)

Saltel F, Chabadel A, Zhao Y, Lafage-Proust MH, Clezardin P, Jurdic P \& Bonnelye E 2006 Transmigration: a new property of mature multinucleated osteoclasts. Journal of Bone and Mineral Research 21 1913-1923. (doi:10.1359/jbmr.060821)

Saltel F, Chabadel A, Bonnelye E \& Jurdic P 2008 Actin cytoskeletal organisation in osteoclasts: a model to decipher transmigration and matrix degradation. European Journal of Cell Biology 87 459-468. (doi:10.1016/j.ejcb.2008.01.001)
Sonoda J, Laganiere J, Mehl IR, Barish GD, Chong LW, Li X, Scheffler IE, Mock DC, Bataille AR, Robert F et al. 2007 Nuclear receptor ERR $\alpha$ and coactivator PGC-1 $\beta$ are effectors of IFN- $\gamma$-induced host defense. Genes and Development 21 1909-1920. (doi:10.1101/gad. 1553007)

Standal T, Borset M \& Sundan A 2004 Role of osteopontin in adhesion, migration, cell survival and bone remodeling. Experimental Oncology 26 179-184.

Stein RA, Chang CY, Kazmin DA, Way J, Schroeder T, Wergin M, Dewhirst MW \& McDonnell DP 2008 Estrogen-related receptor $\alpha$ is critical for the growth of estrogen receptor-negative breast cancer. Cancer Research 68 8805-8812. (doi:10.1158/0008-5472. CAN-08-1594)

Teitelbaum SL 2007 Osteoclasts: what do they do and how do they do it? American Journal of Pathology 170 427-435. (doi:10.2353/ ajpath.2007.060834)

Teyssier C, Gallet M, Rabier B, Monfoulet L, Dine J, Macari C, Espallergues J, Horard B, Giguère V, Cohen-Solal M et al. 2009 Absence of ERR $\alpha$ in female mice confers resistance to bone loss induced by age or estrogen-deficiency. PLoS ONE 4 e7942. (doi:10. 1371/journal.pone.0007942)

Vaananen HK, Zhao H, Mulari M \& Halleen JM 2000 The cell biology of osteoclast function. Journal of Cell Science 113 377-381.

Vanacker JM, Delmarre C, Guo X \& Laudet V 1998 Activation of the osteopontin promoter by the orphan nuclear receptor estrogen receptor related $\alpha$. Cell Growth and Differentiation 9 1007-1014.

Vanacker JM, Bonnelye E, Chopin-Delannoy S, Delmarre C, Cavailles V \& Laudet V 1999 Transcriptional activities of the orphan nuclear receptor ERR $\alpha$ (estrogen receptor-related receptor- $\alpha$ ). Molecular Endocrinology 13 764-773. (doi:10.1210/me.13.5.764)

Weerasinghe D, McHugh KP, Ross FP, Brown EJ, Gisler RH \& Imhof BA 1998 A role for the $\alpha v \beta 3$ integrin in the transmigration of monocytes. Journal of Cell Biology 142 595-607. (doi:10.1083/jcb.142.2.595)

Wilder RL 2002 Integrin $\alpha \mathrm{V} \beta 3$ as a target for treatment of rheumatoid arthritis and related rheumatic diseases. Annals of Rheumatic Disease 61 (Supplement 2) ii96-ii99. (doi:10.1136/ard.61.suppl_2.ii96)

Yumoto K, Ishijima M, Rittling SR, Tsuji K, Tsuchiya Y, Kon S, Nifuji A, Uede T, Denhardt DT \& Noda M 2002 Osteopontin deficiency protects joints against destruction in anti-type II collagen antibodyinduced arthritis in mice. PNAS 99 4556-4561. (doi:10.1073/pnas. 052523599)

Zirngibl RA, Chan JS \& Aubin JE 2008 Estrogen receptor-related receptor $\alpha(\mathrm{ERR} \alpha)$ regulates osteopontin expression through a non-canonical ERR $\alpha$ response element in a cell context-dependent manner. Journal of Molecular Endocrinology 40 61-73. (doi:10.1677/ JME-07-0114)

Received in final form 23 June 2010

Accepted 14 September 2010

Made available online as an Accepted Preprint

14 September 2010 